\title{
УНИКАЛЬНАЯ АРСЕНАТНО-ФОСФАТНАЯ МИНЕРАЛИЗАЦИЯ КЕСТЁРСКОГО ОЛОВОРУДНОГО МЕСТОРОЖДЕНИЯ (ЯКУТИЯ)
}

\section{Яковенчук В.Н., Пахомовский Я.А., Коноплёва Н.Г., Паникоровский Т.Л., Базай А.В., Кривовичев C.B. \\ ФИЦ КНЦ РАН}

С момента открытия в 1937 г. П.П. Епифановым Кестёрского оловорудного месторождения [1] оно привлекает внимание учёных своей необычайно разнообразной фосфатной минерализацией [2-7]. При этом, вплоть до недавнего времени многие находки даже не были надёжно диагностированы, и так и остаются в списке минералов месторождения под названиями «неизвестный фосфат», «фосфат белого цвета», «фосфат зеленый», «Сu-фосфат синий», «фосфат желтый». Тем не менее, с развитием методов локального минералогического и рентгеноструктурного анализов эти пробелы начинают восполняться, - к тому же, как оказалось, некоторые редкие фосфаты обладают интересными функциональными свойствами, в частности, ионной проводимостью.

В ходе изучения современными методами образцов, отобранных первыми тремя авторами в 1987 г. из крупного (5 м в диаметре) кварцево-фосфатного гнезда в грейзенизированных касситеритсодержащих гранодиоритах Кестёрского месторождения (рис. 1), были достоверно установлены амблигонит, аугелит, арсенолит, артурит, гидроксилапатит, лазулит, либетенит, метаторбернит, оливенит, псевдомалахит, самплеит, фторапатит, а также четыре новых фосфата: епифановит, батагаит, Na-аналог батагаита и $\mathrm{Mg}-\mathrm{Zn}$ аналог гопеита (табл. 1).

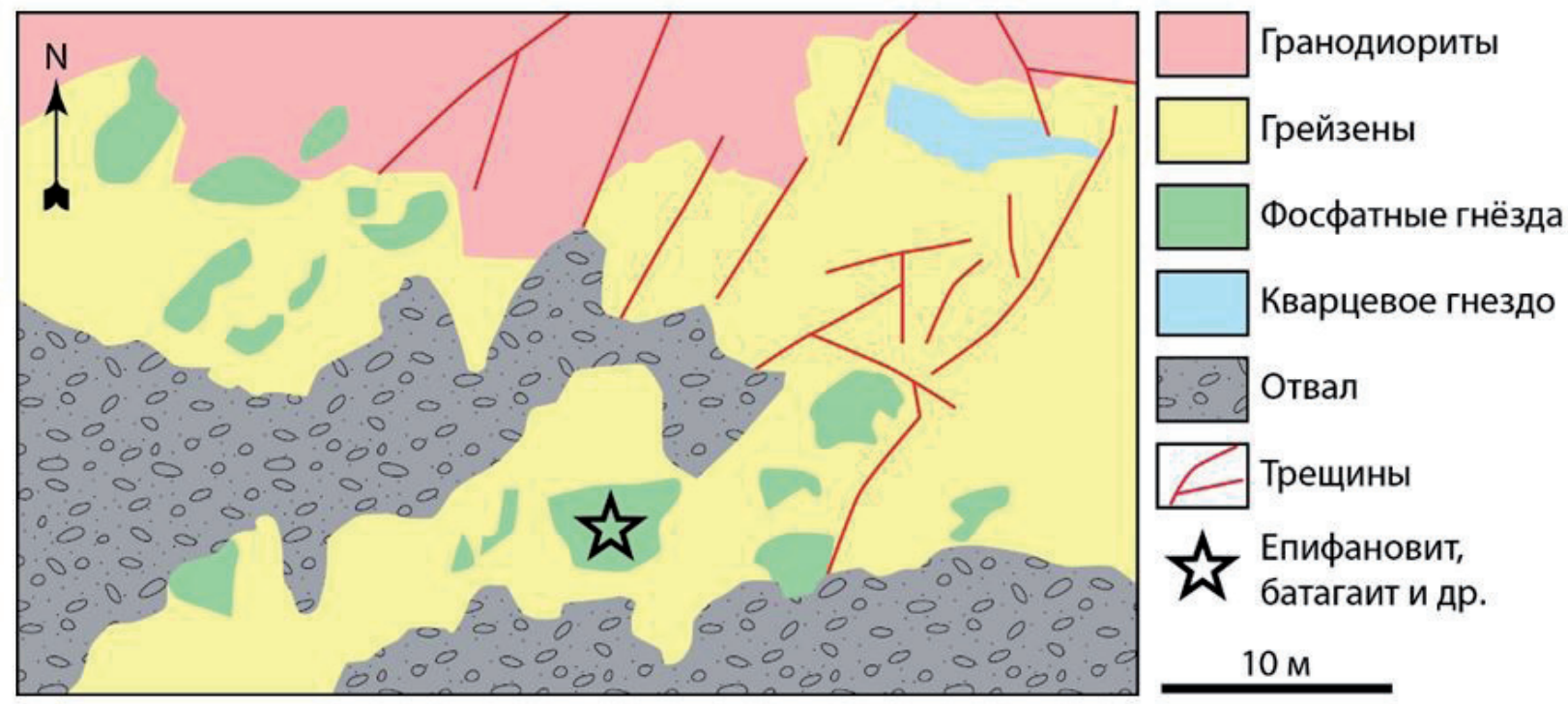

Рис. 1. Фосфатная минерализация Кестёрского месторождения (по М.В. Кокунину [4]).

Это гнездо было сложено колломорфными агрегатами (до 30 см в диаметре) светло-серого карбонатсодержащего фторапатита (штаффелита) и кавернозными сегрегациями молочно-белого кварца (до 10 см). Многочисленные трещины и пустоты во фторапатите и кварце были покрыты тёмно-зелеными кристаллами (до 4 мм в длину) и сферолитами (до 5 мм в диаметре) мышьяковистого псевдомалахита и самплеита (рис. 2 a), друзами бледно-зелёных призматических кристаллов либетенита (до 7 мм в длину, рис. 2 б), травяно-зелёными радиально-лучистыми агрегатами артурита (до 5 мм в диаметре, рис. 2 б), таблитчатых зёрен оливенита (до 3 мм, рис. 2 в) и метаторбернита (рис. 2 г), а также обособленными сегрегациями самородной меди (до 3 мм в диаметре, рис. 2 д).

Бирюзово-голубые таблитчатые кристаллы епифановита (до 50 мкм в длину, рис. 2 е) нарастают на вышеперечисленные минералы меди в тесной ассоциации с бесцветными кубооктаэдрами 

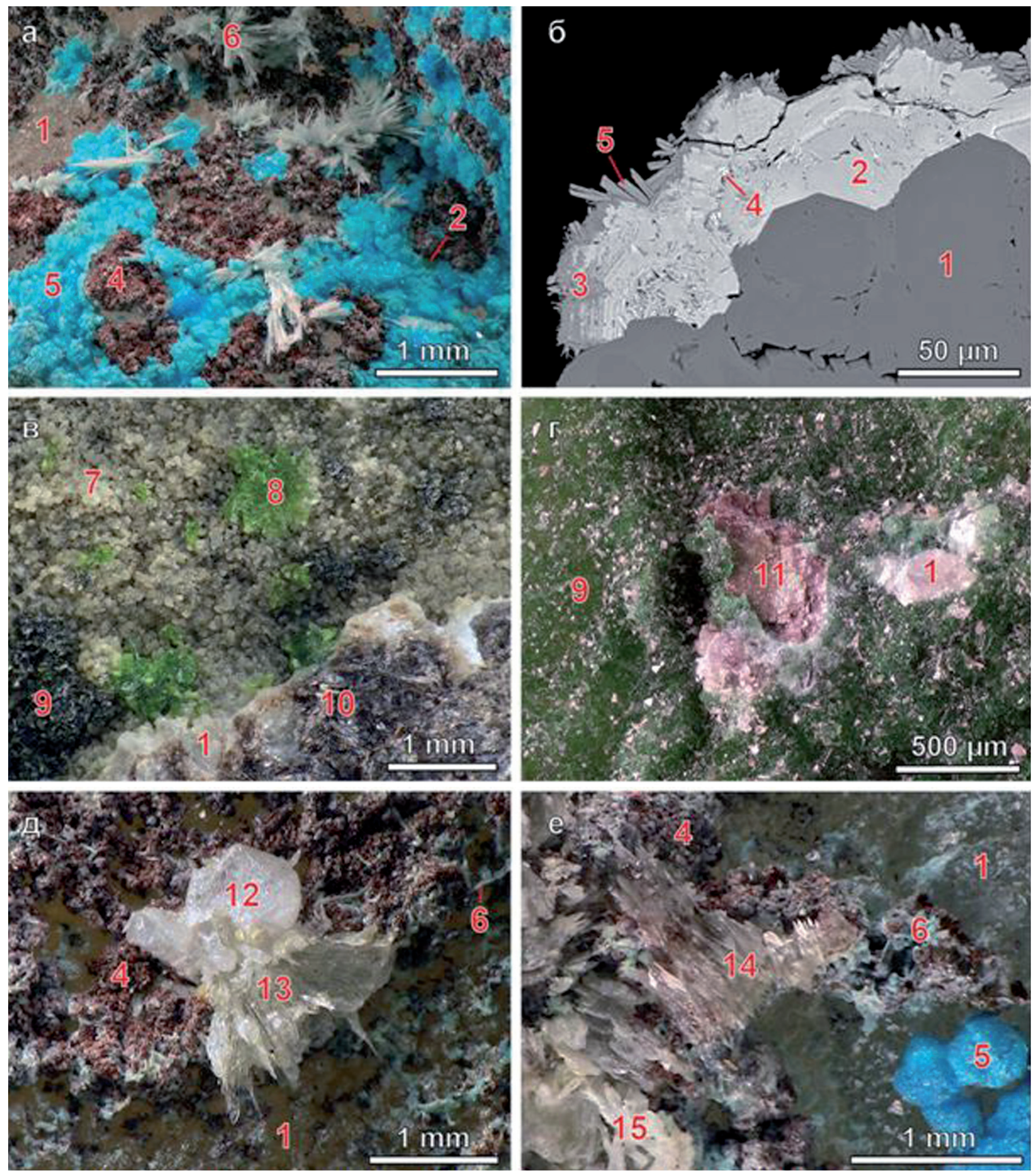

Рис. 2. Редкие фосфаты, арсенаты и ассоциирующие минералы Кестёрского месторождения: 1 - фторапатит (штаффелит), 2 - псевдомалахит, 3 - самплеит, 4 - медь, 5 - епифановит, 6 - Na-аналог батагаита, 7 - либетенит, 8 - артурит, 9 - оливенит, 10 - мусковит- $2 M, 11$ - метаторбернит; 12 - арсенолит, 13 - батагаит, 14 - Mg-Zn-аналог гопеита, 15 - гидроксилапатит.

арсенолита (до 1 мм в диаметре), квадратными зеленоватыми пластинками тоберморита (до 1 мм в диаметре), льдисто-серыми уплощенно-призматическими кристаллами батагаита (рис. 2 ж) и гопеитоподобного Mg-Zn фосфата (до 2 мм в длину, рис. 2 3), а также бледно-зелёными радиальнолучистыми агрегатами Na-аналога батагаита (до 3 мм в диаметре). 
Таблица 1. Состав и параметры элементарной ячейки изученных фосфатов и арсенатов.

\begin{tabular}{|l|l|l|}
\hline \multicolumn{1}{|c|}{ Минерал } & \multicolumn{1}{|c|}{ Формула } & \multicolumn{1}{c|}{$\begin{array}{c}\text { Параметры элементарной } \\
\text { ячейки }\end{array}$} \\
\hline Епифановит & $\mathrm{NaCaCu}_{5}\left(\mathrm{PO}_{4}\right)_{4}\left[\mathrm{AsO}_{2}(\mathrm{OH})_{2}\right] \cdot 7 \mathrm{H}_{2} \mathrm{O}$ & $\begin{array}{l}a=9.69, b=9.74, c=9.96 \AA, \\
\beta=102.2^{\circ}, V=918.7 \AA^{3}, Z=2\end{array}$ \\
\hline Батагаит & $\mathrm{CaZn}_{2}(\mathrm{Zn}, \mathrm{Cu})_{6}\left(\mathrm{PO}_{4}\right)_{4}\left(\mathrm{PO}_{3}(\mathrm{OH})\right)_{3} \cdot 12 \mathrm{H}_{2} \mathrm{O}$ & $\begin{array}{l}a=8.43, b=12.83, c=14.69 \AA, \\
\beta=98.5^{\circ}, V=1571.1 \AA^{3}, Z=2\end{array}$ \\
\hline Самплеит & $\mathrm{NaCaCu}_{5}\left(\mathrm{PO}_{4}\right)_{4} \mathrm{Cl} \cdot 5 \mathrm{H}_{2} \mathrm{O}$ & $\begin{array}{l}a=9.70 b=19.14, c=9.73 \AA, \\
\alpha=\gamma=90^{\circ}, \beta=90.01^{\circ}, \\
V=1805.5 \AA^{3}, Z=4\end{array}$ \\
\hline Метаторбернит & $\mathrm{Cu}_{\left(\mathrm{UO}_{2}\right)_{2}\left(\mathrm{PO}_{4}\right)_{2} \cdot 8 \mathrm{H} 2 \mathrm{O}}$ & $\begin{array}{l}a=6.98, c=8.65 \AA, V=421.3 \\
\AA^{3}, Z=2\end{array}$ \\
\hline Либетенит & $\mathrm{Cu}_{2} \mathrm{PO}_{4}(\mathrm{OH})$ & $\begin{array}{l}a=8.06, b=8.38, c=5.88 \AA, \\
V=404.3 \AA^{3}, Z=4\end{array}$ \\
\hline Оливенит & $\mathrm{Cu}_{2} \mathrm{AsO}_{4}(\mathrm{OH})$ & $\begin{array}{l}a=8.58, b=8.21, c=5.93 \AA, \\
\beta=90.1^{\circ}, V=417.6 \AA^{3}, Z=4\end{array}$ \\
\hline Мg-аналог гопеита & $\mathrm{MgZn}_{2}\left(\mathrm{PO}_{4}\right)_{2} \cdot 4 \mathrm{H}_{2} \mathrm{O}$ & $\begin{array}{l}a=10.63, b=18.37, c= \\
5.02 \AA, V=980.3 \AA^{3}\end{array}$ \\
\hline
\end{tabular}

Последовательность кристаллизации рассматриваемых минералов (медь $\rightarrow$ псевдомалахит $\rightarrow$ либетенит $\rightarrow$ самплеит $\rightarrow$ епифановит $\rightarrow$ батагаит Na-аналог батагаита $\rightarrow$ арсенолит) при низкотемпературной переработке первичных рудных минералов окисляющими гидротермальными растворами свидетельствует о закономерной смене ионного состава минералообразующих растворов по мере их взаимодействия со фторапатитом и осаждения новообразованных фаз: $\mathrm{Cu} \rightarrow \mathrm{CuP} \rightarrow$ $\mathrm{CaCuPAs} \rightarrow \mathrm{CuAs} \rightarrow \mathrm{As}$. Для воспроизводства условий образования фосфатов меди произведён синтез самплеита, либетенита и елисеевита золь-гель методом.

Исследования выполнялись в рамках гранта РНФ 14-17-00071.

\section{Литература}

1. Смирнов С.С., Дубовик М.М., Епифанов П.П. Минералогический очерк Яна-Адычанского района // Тр. Ин-та геол . наук, сер. минер. 1941. Т. 9. Вып. 46.

2. Соболева В.Н. Матер. к минералогии месторождения Кёстер из бассейна реки Яны // Матер. по геологии Северо-Востока СССР. 1949. Вып. 6.

3. Киселёв А.И. Серебро-цинксодержащий станнин из месторождения Арга-Ыннах-Хайской интрузии в бассейне р. Яна // Матер. по геол. и пол. иск. Северо-Востока СССР. 1948. № 3. С. 113.

4. Кокунин М.В. Редкие минералы забытого месторождения // Отечественная геология. 2011. №1. С. 72-82.

5. Яковенчук В.Н., Пахомовский Я.А., Коноплёва Н.Г., Паникоровский Т.Л., Михайлова Ю.А., Бочаров В.Н., Кривовичев С.В., Иванюк Г.Ю. Епифановит $\mathrm{NaCaCu}_{5}\left(\mathrm{PO}_{4}\right)_{4}\left[\mathrm{AsO}_{2}(\mathrm{OH})_{2}\right] \cdot 7 \mathrm{H}_{2} \mathrm{O}$ - новый минерал из месторождения Кестёр (Саха-Якутия, Россия) // ЗРМО. 2017. № 3. С. 30-39.

6. Паникоровский Т.Л., Кривовичев С.В., Яковенчук В.Н., Иванюк Г.Ю. Кристаллическая структура епифановита // ЗРМО. 2017. № 3. С. 39-50.

7. Yakovenchuk V.N., Pakhomovsky Ya.A., Konopleva N.G., Panikorovskii T.L., Bazai A.V., Mikhailova Ju.A., Bocharov V.N., Ivanyuk G.Yu., Krivovichev S.V. Batagayite, $\mathrm{CaZn}_{2}(\mathrm{Zn}, \mathrm{Cu})_{6}\left(\mathrm{PO}_{4}\right)_{4}\left(\mathrm{PO}_{3}(\mathrm{OH})\right)_{3} \cdot 12 \mathrm{H}_{2} \mathrm{O}$, a new phosphate mineral from Këster tin deposit (Yakutia, Russia): characterization and crystal structure // Mineral. Petrol. 2017. Doi: 10.1007/s00710-017-0551-X. 